\title{
Pemuridan Relasional dalam Pelayanan Kaum Muda
}

\author{
Jevin Sengge ${ }^{1}$
}

\section{Pendahuluan}

nti permasalahan dari kaum muda di gereja yang dangkal memahami tentang kekristenan, melihat Tuhan hanya sebagai pengatur etika dan moral, ${ }^{2}$ bertahun-tahun tidak lepas dari dosa pornografi dan yang menurut survei, $60-80 \%$ pada usia dua puluhan dapat dipastikan meninggalkan gereja ${ }^{3}$ adalah karena tidak pernah dididik atau mengalami pengalaman menjadi murid Kristus. Mereka seperti orang muda yang kaya dalam Matius 19 yang tahu kebenaran namun enggan mengikuti-Nya. Alhasil mereka hanya menjadi "petobat tanpa kedalaman", dalam istilah Thom Rainer. ${ }^{4}$
Menurut Harington dan Absalom, ini terjadi karena gereja salah menempatkan fokusnya dan metodologi bergerejanya. ${ }^{5}$ Berdasarkan pengalaman, gereja sedang terjebak dalam rutinitas dan variatif. Rutin itas adalah gereja tidak sedang melakukan "perawatan" (nurturing) jemaat, dan hanya melakukan "pengulangan" tradisi. Gereja tidak berfokus pada jemaat sebagai subjek yang perlu dirawat, melainkan menjadikan dirinya sebagai lembaga Event Organizer (EO) yang kurang berelasi. Harington menyebutini sebagai gereja atraksional, fokusnya acara-acara besar, menarik, dan metodologinya pertunjukan. ${ }^{6}$

1. Jevin Sengge, S.Th., alumnus STT Amanat Agung dan Youth Pastor di Gereja Masehi Injili di Timor (GMIT) AGAPE, Kupang NTT.

2. Christian Smith melakukan sebuah survei singkat kepada kaum muda mengenai pandangan mereka tentang "Tuhan". Ragam pandangan itu kemudian disimpulkannya dalam 5 hal tentang Tuhan: 1.) Tuhan ada dan menciptakan segala sesuatu; 2.) Tuhan ingin ki berbuat baik; 3.) Tujuan hidup ini adalah agar kita berbuat baik; 4.) Ki butuh Tuhan kecuali ada masalah sulit; 5.) Orang baik akan masuk surga ketika mati. Menanggapi jawaban ini, Smith berkesimpulan bahwa "Tuhan" di ma kaum muda hanya dilihat sebagai pengatur etika moral saja. Christian Smith dan Melina Lundquist Denton, Soul Searching: The Religious and Spiritual Lives of American Teenagers (New York: Oxford University Press, 2005).

3. Data dari buku "Discipleshift" mengakan, "Presen kaum pria yang melihat pornografi secara teratur pun sama. Satu dari 4 orang yang hidup bersama di luar pernikahan menyebut dirinya sebagai orang injili. Hanya $6 \%$ yang memberi persembahan persepuluhan secara teratur,... 60-80\% anak muda akan meninggalkan gereja saat mereka memasuki usia dua puluhan." Jim Putmann, Bob Harrington, dan Robert E. Coleman, Discipleshift (Yogyakarm: Yayasan Gloria Katalis, 2016), 23.

4. Bobby Harington dan Alex Absalom, Discipleship that Fits (Yogyakar: Penerbit Kalis, 2018), 11.

5. Putmann, Harrington, dan Coleman, Discipleshift, 28.

6. Putmann, Harrington, dan Coleman, Discipleshift, 30. 


\section{Konteks pergumulan kaum muda hari ini berubah secara cepat. Lima tahun dari sekarang, gereja sudah harus memikirkan ulang soal cara pelayanan kaum muda di gerejanya.}

Sedangkan variatif adalah gereja tidak sedang melakukan inovasi pada diri jemaat, melainkan variatif pada program gereja agar terlihat lebih seru dari tahun sebelumnya. Gereja berpusat pada penambahan jumlah, mengumpulkan persembahan, membicarakan aset, dan pembangunan gedung fisik. Gereja tidak berpikir soal pemuridan.

Dalam makalah ini, penulis akan membahas tentang pemuridan yang relasional sebagai salah satu kunci pemuridan bagi kaum muda. Penulis akan menjabarkan tentang apa itu pemuridan kaum muda, bagaimana relasi dapat menjadi kunci melakukan pemuridan, dan mengapa pemuridan penting untuk kaum muda.

\section{Kaum Muda, Konteks, dan Kebutuhan}

Pelayanan kaum muda bukanlah pelayanan yang mudah. Konteks pergumulan kaum muda hari ini berubah secara cepat. Lima tahun dari sekarang, gereja sudah harus memikirkan ulang soal cara pelayanan kaum muda di gerejanya.
Meskipun banyak perubahan, kebutuhan kaum muda di setiap zaman tidak pernah berubah. Relasi, teladan, dan ruang mengekspresikan diri merupakan tiga kebutuhan utama seorang kaum muda. Ketika memasuki usia muda, ia akan bergumul soal relasi dan keintiman. Selain itu, krisis pencarian jati diri juga menuntut mereka menemukan model atau teladan yang tepat untuk diikuti. Pada waktu yang sama, mereka ingin merasa diakui eksistensi dirinya. Itulah pentingnya ada ruang di mana mereka dapat mengekspresikan diri secara bebas.

Konteks dunia kaum muda hari ini menjadi tantangan besar untuk gereja. Generasi muda hari ini sedang berada di dunia yang maju, cakap membaca kebutuhan dan mampu memberi kesenangan. Maju dalam arti memiliki dunia yang global dalam ilmu pengetahuan yang didukung oleh sistem digital yang memampukan seseorang memiliki ribuan informasi yang dapat diakses dengan mudah. Cakap membaca kebutuhan artinya hal-hal di luar gereja mampu memenuhi kebutuhan dengan cara yang mudah dan instan. Misalnya aplikasi-aplikasi media sosial bahkan kencan untuk memenuhi kebutuhan relasi. Sayangnya, gereja tidak cukup mengantisipasi soal ini. Hasil penelitian masih menunjukkan bahwa $25 \%$ anak muda merasa bahwa kekristenan itu anti ilmu pengetahuan. ${ }^{7}$ Hal-hal itu membuat mereka mendapat kesenangan yang tidak didapati mereka di dalam gereja. Apalagi ketika gereja didominasi oleh generasi

7. Tan Giok Lie, Generasi ke Generasi (Bandung: Visi Anugerah Indonesia, 2017), 202.

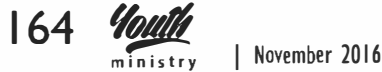


tua yang mempertahankan status quo dan anti dengan perubahan zaman. ${ }^{8} \mathrm{Hal}$ ini semakin menjauhkan mereka dari proses menjadi murid.

Gereja dan pembina Kaum Muda perlu sadar tentang hal ini. Di dalam melakukan pemuridan pada kaum muda, konteks dunia dan kebutuhan kaum muda di atas menjadi pertimbangan utama sebelum memulainya. Kebutuhan ini dapat dijembatani dengan mengadakan sebuah gerakan pemuridan relasional. Pemuridan ini adalah model yang tidak mengukur keberhasilan dari berapa banyak orang yang datang ke gereja, berapa banyak persembahan yang dikumpulkan, atau petobat yang dihasilkan. Model ini mengukur keberhasilan dari berapa banyak orang yang dikasihi dan dibimbing ke jalan Yesus, datang kepada Kristus dan mengikut Dia. ${ }^{9}$ Fokusnya jelas Yesus, metodenya adalah relasional.

\section{Pemuridan Relasional dalam Alkitab}

Mengapa relasi? Tanpa relasi, tidak mungkin tercapai perubahan. Tanpa relasi tidak akan ada model yang dapat diteladani, seperti cara Paulus kepada Timotius yang muda (2Tim 2:1-2), atau Yesus terhadap 12 murid Tanpa relasi, eksistensi diri seseorang tidak dapat tersentuh. Harington mengatakan bahwa cara pemuridan Yesus bersifat relasional dan pribadi. Ketimbang terfokus pada banyak orang, waktu Yesus lebih banyak dipakai untuk interaksi bersama 12 murid-Nya yang kemudian lebih efektif untuk menjangkau banyak orang. ${ }^{10}$

Pemuridan relasional bersifat persahabatan. Yohanes 15:15 menuliskan Yesus tidak lagi menyebut murid-murid-Nya hamba, melainkan sahabat karena Ia telah memberitahukan segala hal dari Bapa. Dengan katalain, proses pemuridan Yesus selama 3 tahun bersama murid-muridNya adalah sebuah bentuk persahabatan. Maka, proses pemuridan seperti inilah yang patut menjadi contoh pemuridan hari ini.

Yesus menjadikan diri-Nya sebagai sahabat spiritual. Persahabatan ini adalah persahabatan yang berakar di dalam Kristus untuk tujuan bertumbuh di dalam Kristus. Nindyo Sasongko menyebut "Sahabat Spiritual" dengan istilah "Spiritual Companion". Kata ini terambil dari dua kata, yakni: "Cum" (bersama) dan "Panis" (roti), yang artinya roti yang dinikmati bersama. Sahabat Spiritual adalah seorang sahabat yang menjadi rekan, sahabat peziarahan spiritual yang rindu mencari Allah dan di mana ia berani berbagi hidup dan hal yang pokok dalam hidupnya. ${ }^{11}$

Hal ini semakin jelas ketika menelaah kisah pemuridan di dalam catatan Yohanes 1:29-43. Pemuridan ini dimulai dengan relasi Yohanes pembaptis yang kemudian mengenalkan dua orang muridnya kepada

8. Lie, Generasi ke Generasi, 204.

9. Putmann, Harrington, dan Coleman, Discipleshift, 36.

10. Harington dan Absalom, Discipleship that Fits, 41.

11. Nindyo Sasongko, "Kala dan Kalam," 25 April 2016, https://www.youtube.com/watch?v=lS6C8P7--IA\&t=885s (diakses pada 30 Agustus 2018). 
Yesus yang kemudian mengikuti-Nya (ayat 36, 37). Lalu Yesus berelasi dengan dua orang murid tersebut dengan bertanya, "Apakah yang kamu cari?" (ayat 38). Hal ini dilakukan Yesus dengan maksud mengetahui motivasi mereka. Dan tidak hanya itu, relasi mereka kemudian dilanjutkan dengan catatan "Merekapun datang dan melihat di mana Ia (Yesus) tinggal, dan hari itu mereka tinggal bersamasama dengan Dia,..." (ayat 39) Yesus menjadi sahabat spiritual yang berbagi hidup dengan dua orang murid tersebut.

Hal ini kemudian dicontoh oleh Paulus dalam memuridkan Timotius yang muda. 2 Timotius 3:10-11 menuliskan:

"Tetapi engkau telah mengikuti ajaranku, cara hidupku, pendirianku, imanku, kesabaranku, kasihku dan ketekunanku. Engkau telah ikut menderita penganiayaan dan sengsara seperti yang telah ku derita di Antiokhia dan di Ikonium dan di Listra. Semua penganiayaan itu kuderita dan Tuhan telah melepaskan aku daripadanya."

Pemuridan yang dilakukan oleh Paulus bukan sekadar mengajarkan atau mendikte, melainkan berbagi hidup sebagai sahabat spiritual.

\section{Pemuridan Relasional pada Kaum Mu- da}

Pemuridan harus dimulai dengan relasi. Pemuridan relasionaladalah pemuridan yang mengutamakan relasi di dalam gaya

\section{Pemuridan harus dimulai dengan relasi. Pemuridan relasional adalah pemuridan yang mengutamakan relasi di dalam gaya pemuridannya.}

pemuridannya. Gallaty mengatakan, "Pemuridan adalah secara sengaja memperlengkapi orang percaya dengan firman Allah melalui relasi bertanggung jawab yang dimampukan oleh Roh Kudus untuk menghasilkan pengikut Kristus yang setia."12

Mengapa harus relasi? Tim Schmoyer mengatakan secara gamblang, "Teenagers come to youth group primarily because of the relationship. The reverse of this is also true: Students who aren't connected in meaningful relationships in the youth mininstry don't care to be there." 13 Tujuan kedatangan mereka ke kelompok pemuda adalah relasi, maka kebutuhan ini perlu dipikirkan sebagai alat penjangkauannya.

Relasi yang perlu dibangun harus mencakup 4 ukuran ini, yakni "Loving, Caring, Modeling, dan Corporate". "Loving" berbicara mengenai seberapa besar kaum muda merasa dikasihi. Kasih adalah dampak terbesar untuk memuridkan kaum muda. Mereka tidak terlalu mementingkan seberapa bagus sebuah acara dibuat di gereja, atau sebaik apa program yang

12. Robby Gallaty, Rediscovering Discipleship (Yogyakarta: Perkantas, 2018), 149.

13. Tim Schmoyer, Life Student Ministry: Practical Conversations on Thriving in Youth Ministry (Grand Rapids: Zondervan, 2011), 24.

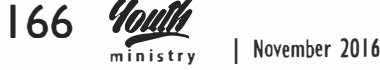


dirancangkan bagi mereka. Selama mereka tidak merasa dikasihi, perkumpulan kaum muda bukan untuk dirinya. Schmoyer mengatakan, "... the greatest impact we can have is just by showing teens that we love them and that God does, too." 14

"Caring" adalah tentang mengenal diri dari kaum muda tersebut. Para kaum muda tidak terlalu mementingkan tentang seberapa baik para pemimpinnya menguasai doktrin teologi, atau sebagus apa khotbah mereka. Hal yang mereka pentingkan adalah sebaik apa pemimpin mengenal tentang mereka. Khotbah pun akan lebih kontekstual dengan kehidupan mereka jika pemimpin berelasi atau mengenal siapa kaum mudanya.

Dalam hal ini, maka perkunjungan (visitation) menjadi hal yang sangat penting untuk dilakukan. Hal yang salah dari perkunjungan di gereja-gereja adalah mereka mendatangi kaum muda hanya untuk meminta mereka kembali datang ke persekutuan. Ini jelas bukan untuk menunjukkan kepedulian, melainkan tuntutan program gereja yang menuntut jumlah kehadiran. Perkunjungan sebaiknya dilakukan karena kepedulian (caring). Ajak mereka bertemu, makan siang bersama, atau nonton bioskop, dan sebagainya adalah cara perkunjungan yang baik hari ini.

Sedangkan "Modeling" menunjuk pada peran pemimpin sebagai teladan (Role model) bagi kaum muda. Kaum muda adalah orang-orang yang mencari teladan dan

\section{Kaum muda tidak suka dengan relasi yang tertutup. Mereka menuntut keautentikan diri bukan kemunafikan atau kepura-puraan.}

terinspirasi melalui kehidupan orangorang yang menjadi teladan. Seorang pemimpin pemuridan harus lebih dahulu menunjukkan keteladanan hidup sebagai murid Kristus yang baik untuk kemudian dapat diteladani. Kaum muda perlu percaya bahwa pemimpin yang mereka ikuti adalah pemimpin yang tepat untuk diteladani.

Ini kesulitannya, kaum muda tidak suka dengan relasi yang tertutup. Mereka menuntut keautentikan diri bukan kemunafikan atau kepura-puraan. Pemimpin yang tidak dapat memahami cara mereka akan mendapat penolakan langsung dari kaum muda. Mereka perlu merasakan bahwa semua manusia adalah orang berdosayang berupaya untukberubah, hanya pemimpin kaum muda sudah selangkah lebih maju daripada mereka. Maka itu tuntun mereka untuk melangkah lebih baik ke depan. Schmoyer mengatakan, "The best way to build trust is to model vulnerability and let them see that you're real person who's not afraid to be open and authentic." 15 
Tan Giok Lie memberikan beberapa kiat praktis di dalam menjangkau kaum muda hari ini yakni: ${ }^{16}$

1. Tunjukkan contoh hidup riil, sebab kehidupan riil Anda berbicara lebih keras kepada mereka daripada perkataan.

2. Adakan waktu cukup untuk berdialog tentang hal-hal yang interdisipliner termasuk hal-hal yang mungkin kontroversial/paradoks.

3. Berikan telinga untuk mendengarkan kisah pribadi yang sedang "menjerit" dengan suatu keyakinan bahwa setiap kisah kehidupan itu penting adanya.

4. Berikan alternatif solusi permasalahan dari perspektif kristiani.

5. Libatkan mereka untuk berkontribusi atau berpartisipasi dalam pelayanan/misi berkaitan dengan potensi dan minat mereka sebagai orang muda.

Kiat-kiat ini jelas sangat sarat dengan kebutuhan relasional di atas.

Selanjutnya, pemuridan relasional kepada kaum muda sebaiknya dilakukan dalam sebuah kelompok. Alasan pertama adalah karena Yesus sendiri membangun pemuridan di dalam bentuk kelompok. Alasan kedua, karena di dalam kelompok, kaum muda mendapat ruang untuk berekspresi. Alasan ketiga, menurut Gallaty, pemuridan perorangan terlihat menakutkan, seperti sesi konseling, memberikan kebergantungan pada pemimpin dan cenderung sempit di dalam pembahasannya. ${ }^{17}$

Oleh karena itu, dalam hal ini, pemimpin kaum muda perlu melakukan "Corporate" atau kerja sama. Ia tidak dapat mengendalikan semua kelompok. Ia butuh melibatkan orang-orang yang dewasa dalam iman dan karakter Kristus untuk menolong dia memuridkan kaum muda. Ia butuh memilih pemimpin yang dapat menjadi teladan, entah itu majelis, sesama pelayan gereja atau orang tua yang telah menjadi murid Kristus. Hal ini akan menolong kaum muda untuk melihat bahwa sebagai satu tubuh Kristus, gereja saling merawat dan menumbuhkan antara satu dengan yang lainnya.

\section{Mengapa Kaum Muda Penting Dimu- ridkan?}

Ada empat alasan mengapa hal ini penting, yakni: pertama, pemuridan adalah bagian dari misi Allah. Pemuridan itu bersifat "Trans-generations". Menurut Tan Giok Lie, mandat pendidikan Kristiani harus bersifat estafet, bahwa perjanjian Tuhan yang diikat dengan seorang kepala keluarga wajib diteruskan kepada generasi selanjutnya secara turun temurun. ${ }^{18}$ Inilah juga alasan di dalam Perjanjian Lama, Allah disebut dengan sebutan "Allah Abraham, Ishak dan Yakub." Allah harus menjadi Allah tiap generasi. Tentu maksudnya bukan hanya tiga generasi, tetapi

16. Lie, Generasi ke Generasi, 212-213.

17. Gallaty, Rediscovering Discipleship, 141-145.

18. Lie, Generasi ke Generasi, 124-125. 
trans-generations, Allah menjadi Allah tiap orang, di tiap masa hingga kedatangan Yesus Kristus. Sebagaimana Paulus mengingat iman yang tulus ikhlas yang turun dari nenek Lois, dan ibu Eunike dan kemudian pada Timotius (2Tim. 2:5). Jadi, pemuridan semata-mata adalah sebuah usaha dimuridkan untuk memuridkan. Bayangkan jika kaum muda hari ini tidak dimuridkan, maka generasi berikutnya akan terancam. Jadi ingatlah, setiap kali kita berkhotbah kepada kaum muda, kita sedang berkhotbah juga untuk anak-anak mereka yang belum lahir.

Kedua, gereja yang tidak berpikir soal kaum mudanya adalah gereja yang sedang menggali lubang kuburnya sendiri. $\mathrm{Bu}-$ kankah itulah yang terjadi di negaranegara bagian Eropa? Mereka tidak cukup memberi perawatan yang tepat pada nutrisi pertumbuhan iman kaum muda. Akibatnya kaum muda ini mengonsumsi nutrisi-nutrisi dunia dan kemudian menyangkali Tuhan.

Ketiga, jika gereja Anda sudah sadar akan hal ini, pemuridan menjadi penting karena kita harus sadar bahwa 10 tahun mendatang, kaum muda di gereja inilah yang akan menggantikan posisi para pemimpin gereja hari ini. Jika mereka tidak dipersiapkan menjadi murid Kristus, maka akan ada dua kemungkinan: 1) Mereka yang menduduki kursi pemimpin gereja adalah pemimpin yang belum lahir baru; atau 2) para pemimpin gereja tidak memiliki pengganti yang tepat, alias gere- ja menuju kepada kematiannya.

Keempat, alasan sederhananya adalah karena Anda rindu melihat kaum muda bertumbuh dalam iman mereka kepada Tuhan. Ketika bangku-bangku persekutuan masih banyak yang kosong. Kaum muda datang dan pergi tanpa mengetahui mengapa mereka harus mengenal Tuhan. Kelompok-kelompok persekutuan Anda mulai berkurang jumlah nya. Tentu Anda mulai berpikir tentang apa yang salah dan apa yang mereka butuhkan.

Alasan terakhir adalah karena pertumbuhan iman kaum muda bukan didasarkan pada program-program atau serunya kegiatan-kegiatan gereja, tetapi proses kesadaran tentang siapa dan apa panggilan Tuhan atas diri mereka. Hasil riset dari Barna Group of Ventura, California menunjukkan bahwa mereka yang aktif pada kegiatan gereja di masa remaja (teens) tidak cukup stabil untuk menjaga kehidupan spiritualitas mereka ketika memasuki masa pemuda (adulthood).$^{19}$ Informasi dari Rainer Research juga menunjukkan bahwa sekitar 70\% dari pemuda di Amerika drop out dari gereja mulai usia sekitar 18 hingga 22 tahun..$^{20}$ Maka, jika gereja hanya berpikir tentang jumlah kehadiran dan program kegiatan yang harus diberikan. Gereja sedang membentuk seorang "pendatang" saja di gereja, dan bukan "Pejuang" iman. David W. Robbins mengatakan, "All of us who love teenagers and care about nurturing in them a long-term commitment would

19. Duffi Robbins, Building a Youth Ministry that Builds Disciples (Grand Rapids: Zondervan, 2011), 17.

20. Robbins, Building a Youth Ministry that Builds Disciples, 17. 


\section{Kebutuhan relasi, model dan pengakuan ini menjadi sangat penting untuk dipertimbangkan. Maka seorang pelayan kaum muda perlu menjembatani hal ini dengan melakukan pemuridan relasional.}

agree that if we want to encourage in our students a faith that does not fail or fade, we need to focus on strategies that encourage survival, not just arrival."21

\section{Kesimpulan}

Pemuridan kaum muda hari ini perlu memperhatikan konteks dan kebutuhan kaum muda. Kebutuhan relasi, model dan pengakuan ini menjadi sangat penting untuk dipertimbangkan. Maka seorang pelayan kaum muda perlu menjembatani hal ini dengan melakukan pemuridan relasional.
Pemuridan relasional menuntut seorang pelayan kaum muda untuk menjadi sahabat spiritual, yakni orang yang dapat menjadi rekan bagi kaum muda dalam peziarahan iman mereka dengan cara berbagi hidup. Di samping itu, pemuridan relasional harus memenuhi 4 kriteria, yakni: Loving, Caring, Modeling, dan Corporate. Alasannya sederhana, karena Yesus sendiri memuridkan dengan relasi yang seperti ini.

Penulis paham bahwa tulisan ini terlampau jauh dari apa yang menjadi kebutuhan pemuridan kaum muda hari ini. Ada banyak hal yang tidak dibahas, misalnya kendala-kendala pemuridan kaum muda, sisi rohaniwan kaum muda sendiri, dan lintas generasi dalam pemuridan hari ini (misalnya Generasi X, Y, Z, dan Alpha). Maka itu, penulis mendorong pembaca untuk melakukan penyelidikan lebih lanjut untuk mendorong terciptanya sumbersumber tulisan kaum muda yang lebih banyak dan memajukan pelayanan kaum muda.

21. Robbins, Building a Youth Ministry that Builds Disciples, 18. 


\section{Daftar Pustaka}

Gallaty, Robby. Rediscovering Discipleship. Yogyakarta: Perkantas, 2018.

Harington, Bobby dan Alex Absalom. Discipleship that Fits. Yogyakarta: Penerbit Katalis, 2018.

Lie, Tan Giok. Generasi ke Generasi. Bandung: Visi Anugerah Indonesia, 2017.

Putmann, Jim, Bob Harrington dan Robert E. Coleman. Discipleshift. Yogyakarta: Yayasan Gloria Katalis, 2016.

Robbins, Duffi. Building a Youth Ministry that Builds Disciple. Grand Rapids: Zondervan, 2011.

Sasongko, Nindyo. "Kala dan Kalam." 25 April 2016. https://www.youtube.com/ watch?v=lS6C8P7--IA\&t=885s (diakses pada 30 Agustus 2018).

Schmoyer, Tim. Life Student Ministry: Practical Conversations on Thriving in Youth Ministry. Grand Rapids: Zondervan, 2011.

Smith, Christian dan Melina Lundquist Denton. Soul Searching: The Religious and Spiritual Lives of American Teenagers. New York: Oxford University Press, 2005. 